\title{
Mistä ja miten uusia yrittäjiä maaseudulle?
}

Jarna Heinonen (2000). Mistä uusia yrittäjiä maaseudulle? Puheenvuoro maaseutuyrittäjyydestä. Turun kauppakorkeakoulu / Yritystoiminnan tutkimus- ja koulutuskeskus, PK-Instituutti / B 1.

\section{"Mistä uusia yrittäjiä} maaseudulle?" -tutkimuksen lähtökohtana on tarve ja halu pitää suomalainen maaseutu elävänä ja asuttuna. Maaseutuyrittäjyyden Edistämiskeskus (MAEK) selvitti, onko maamme kaupunkiväestöllä aitoa kiinnostusta siirtyä yrittäjiksi maaseudulle. Elintarviketieto
Oy toteutti vuosina 19992000 kyselytutkimuksen, jossa tutkittiin kaupunkilaisten maallemuuttohalukkuutta yli 50000 asukkaan kaupungeissa. Turun kauppakorkeakoulun PK-Instituutti kokosi tulokset raportin muotoon.

\section{Tutkimus lähestyy maa-} seutuyrittäjyyttä yrityskirjallisuuden kautta. Raportissa hahmotetaan, mitä maaseutuyrittäjyydellä ymmärretään, käsitellään maaseutua yrittäjyyden kohdealueena ja perehdytään yrittäjyyteen uutta luovana prosessina. Raportin empiirinen aineisto kuvaa kaupunkiväestön kiinnostusta siirtyä maaseudulle yrittäjiksi tai työhön. Johtopäätöksinä esitetään ehdotuksia maallemuuttoa edistävistä toimenpiteistä ja aihetta syventävistä jatkotutkimuksen kohteista.

Teknologian kehittyminen on tuonut maaseudulle uusia liiketoimintamahdollisuuksia ja kokonaisia toimialaryhmiä, jotka houkuttelevat uudenlaista osaamista ja aloitteellisia toimijoita. Maaseudun yrittäjyys ei rajoitu enää vain maatalouteen liittyvään yritystoimintaan. Maaseudulla on jo runsaasti lähimarkkinoille suuntautuneita, elinkaarensa alkuvaiheissa olevia sekä voimakkaasti teollisuuteen keskittyneitä pienyrityksiä. 


\section{Maaseudun elinvoimai-} suus kumpuaa raportin mukaan kahdesta ilmiöstä: yittäjyyden innovatiivisesta voimasta maaseudulla sekä maaseudun ja kaupunkien välisestä yhteistyöstä. Maaseudun ja kaupunkien vuorovaikutuksen kautta voivat uudet toiminta- ja yhteistyövaihtoehdot tulla näkyviksi ja mahdollisiksi. Kaupunkiväestön siirtyminen maaseudulle mahdollistaa paitsi määrällisesti myös sisällöllisesti maaseutuyrittäjyyden kehittymisen.

\section{Lista maaseutuyrityksen}

menestys- ja uhkatekijöistä ei juurikaan poikkea sellaisesta yrityksestä, joka toimii muualla kuin maaseudulla. Menestyvän yrityksen edellytykset perustuvat liikeideaan, yrittäjyysprosessiin ja yrittäjän liiketoimintaosaamiseen. Maaseutu sijaintipaikkana on yrittäjälle sinänsä merkityksellinen, mutta yrittäjyyden näkökulmasta toissijainen. Yrittäjyys on samankaltainen prosessi eri toimintaympäristössä. Päätös yrittäjäksi ryhtymisestä perustuu henkilön yleisiin taustatekijöihin, henkilötekijöihin sekä objektiiviseen todellisuuteen. Motiivit ovat aina henkilökohtaisia.

\section{Yrittäjyysprosessi syntyy} kolmen tekijän, yrityksen perustajan, mahdollisuuksien ja tarvittavien resurssien huolellisesta arvioinnista. Ympäristön epävarmuus on omiaan synnyttämään yrittäjyyttä. Yrittäjyyden innovatiivisesta luonteesta johtuen yrittäjyyttä ja mahdollisuuksien havaitsemista ei voida varsinaisesti opettaa. Tietoa voidaan kuitenkin lisätä, jolloin mahdollisuuksien havaitseminen ja ideointikyky usein paranevat.

\section{Raportissa kuvataan}

yrittäjyysprosessin lopputulosta tilan muutokseksi. Yrittäjyys on ennen muuta tulemisen ja muuttumisen prosessi ei niinkään olemisen tila.

\section{Maaseudun elinvoimai-} suudessa oleellisesta on maaseudun väestö ja väestön toimeentulo- ja elinkeinopohja. Ainakin toistaiseksi maaseudun ja kaupunkien välinen väestövirta on kulkenut maaseudulta kaupunkeihin, ja ennen muuta kasvukeskuksiin. Raportissa esitetty maaseudun visio lähtee kuitenkin siitä, että tulevaisuudessa maaseutu saisi peräti lievää muuttovoittoa kaupungeista.

\section{Tutkimuksessa selvitettiin} kaupunkilaisten muuttohalukkuutta puhelinhaastattelulla. Kysely tehtiin noin 2 000:1le, iältään 15-64 -vuotiaille henkilöille, jotka asuivat yli 50000 asukkaan kaupungeissa. Kysely toteutettiin vuosien 1999-2000 vaihteessa.

\section{Raportin empiirisen} osan tuloksista käy ilmi, että tutkituissa kaupungeissa noin 260000 henkilöä on kiinnostunut maaseudulla työskentelystä tai yrittämisestä. Näistä noin 65000 harkitsi vakavasti maalle muuttamista. Kiinnostus oli jonkin verran suurempaa pääkaupunkiseudulla kuin muissa kaupungeissa. Keskimääräistä suurempaa muuttamishalukkuus oli 25-44 -vuotiaiden, johtavassa asemassa olevien, ylempien toimihenkilöiden ja yrittäjien keskuudessa sekä perheissä, joissa asui kaksi nuorta aikuista tai joiden lapset olivat alle kouluiässä. Myös koulutustason kohoaminen näytti lisäävän muuttokiinnostusta.

\section{Tutkimuksen kiintoisin}

ryhmä olivat ne runsaat 65000 henkilöä, jotka ovat todennäköisesti siirtymässä maaseudulle esteiden poistuessa. Nämä maalle muuttamista vakavasti harkitsevat olivat jo pystyneet luomaan toimeentulolleen ja elämiselleen riittävät edellytykset. Kyseeseen tulivat lähinnä ryhtyminen yrittäjäksi, työpaikan löytäminen tai etätyöskentely maaseudulta käsin. Yli puolella oli jo käsitys siitä, millaisessa ammatissa tai minkä yritysidean varassa he tulisivat maalla toimimaan.

\section{Noin 80 prosentille}

kaupunkilaisista maaseudulle muuttaminen ei ollut realistinen vaihtoehto. Näistä prosentille muuttaminen ei ollut edes juolahtanut mieleen. Todennäköisesti syynä tähän on yleinen tietämättömyys ja/tai välinpitämättömyys maaseudun mahdollisuuksista. Runsas kolmannes kielteisesti vastanneista piti kaupunkia yksiselitteisesti parempana asuinvaihtoehtona. Runsas neljännes mainitsi syyksi kaupungissa sijaitsevan työpaikan. Myös koulutusta ja ammattia vastaavan työn saanti nähtiin ongelmallisena, samoin perhesyyt, liikenneyhteydet, harrastemahdollisuudet ja sosiaaliset kontaktit.

\section{Tutkimus nostaa esille}

kaksi teemaa, joita tulisi painottaa maaseutuyrittäjyyden edistämistyössä: kehittämispanosten suuntaaminen kaupunkeihin oikeille kohderyhmille ja maaseudulla olemassa olevan toiminnan kehittäminen ja kasvattaminen. Raportti ehdottaa kohderyhmittäin räätälöityjä toimenpiteitä maaseutuyrittäjyyden edistä- 
mistyötä tekevien työkaluiksi.

\section{Niiden kaupunkilaisten}

ryhmä, joille maaseudulle siirtyminen ei ollut tullut lain-

kaan mieleen, tarvitsee raportin mukaan tietoa maaseudun olemassaolosta, elämäntavasta ja maaseudun realistisista mahdollisuuksista. Osa henkilöistä saattaa arvioida maaseudun mahdollisuuksia uudestaan uuden tiedon pohjalta; ryhmän asenteet maaseutua kohtaan eivät missään tapauksissa olleet kielteisiä.

Se kaupunkilaisten ryhmä, joka piti kaupunkimuotoista asumista maaseutua parempana vaihtoehtona, näki maaseudun todennäköisesti jossain määrin negatiivisessa valossa. Koska ryhmä omasi vahvasti asenteellisia mielikuvia, vaikuttaminen lyhyellä aikavälillä ei liene heihin mahdollista. Pitkällä aikajänteellä on kuitenkin tärkeää pyrkiä luomaan myös näille henkilöille positiivisia näkemyksiä maaseudun mahdollisuuksista ja varmistaa, että maallemuutto voi näyttäytyä jossain elämänvaiheessa heillekin tarkoituksenmukaisena vaihtoehtona.

Ne kaupunkilaiset, jotka pitivät maalle muuttamista kiinnostavana vaihtoehtona (260 000 henkilöä), mutta kokivat sen esteeksi yksittäisiä tekijöitä, ovat raportin mukaan haasteellisin ryhmä. Olennaista on ensiksi selvittää, ketkä tästä ryhmästä ovat vakavasti muuttoa harkitsevia ja ketkä pelkästään elämänmuutoksesta unelmoivia. Vakavasti asiaa pohtivien $(65000$ henkilöä) osalta maalle muuton esteet tulisi ensin pyrkiä poistamaan. Ensisijaisesti kyse on siirtyjien toimeentulomahdollisuuksien varmistamisesta uudessa toimintaympäristössä. Myös kysymyksiin siitä, mitä maaseudulla asuminen tarkoittaa ja miten perhe tulee sopeutumaan uuteen ympäristöön, tulisi tarjota ohjausta ja vastauksia.

\section{Vakavasti muuttoa}

harkitsevien ryhmää tulisi myös rohkaista tunnistamaan todelliset muuttoon liittyvät kannusteensa, mikäli ne ovat olemassa. Kannusteita voivat olla mm. kustannustaso, elämänlaatu, asumiseen liittyvät hyödyt jne. Tiedotus ja konkreettiset maaseutuun liittyvät kokemukset antavat ryhmälle mahdollisuuden realistisesti arvioida omaa tulevaisuuttaan maaseudulla.

\section{Koska yrittäminen maa-} seudulla on samanlainen prosessi kuin muussakin toimintaympäristössä, maaseudun elinkeinopolitiikka ja pk-politiikka olisi nähtävä osana yleistä elinkeinopolitiikkaa ja viime kädessä osana valtakunnan talouspolitiikkaa. Tutkimusraportin eräänä tarkoituksena on lisätä yleistä keskustelua maaseutuyrittäjyyden monista ulottuvuuksista ja kaupunkien ja maaseudun välisestä vuorovaikutuksesta. Yrittäjyys on voimavara, jota ei ole varaa olla käyttämättä maaseutua rakennettaessa. Kaupunkilaisten osaaminen ja tietotaito on kullanarvoista pääomaa, jota tulisi voida siirtää ja käyttää vuorovaikutteisesti maaseudun hyväksi. Monet maaseutuyrittäjyyden innovaatioista ovat syntyneet kaupungeista saadun kokemuksen ja tiedon pohjalta.

\section{Raportissa korostetaan}

tiedon ja itsetutkistelun merkitystä. Päätös maalle siirtymisestä syntyy vasta, kun henkilön taustatekijät, henkilötekijät ja tulkinta omasta elämäntilanteesta tuottavat siirtymistä tukevan lopputuleman.

Tämä näkökulma avaa monia mahdollisuuksia yrittäjyyskoulutukselle ja-kasvatukselle.

Vaikka tutkimuksessa ei selvitetty osaamisvajetta maalle siirtymisen esteenä tai tarvetta uuteen tai lisäkouluttautumiseen, tutkimuksen pohjalta on pääteltävissä, että kohderyhmittäin räätälöity koulutus voi tukea merkittävällä tavalla yksilön päätöksentekoa ja tällaisen koulutuksen kehittäminen on tarpeellista. Yleisellä yrittäjyyskasvatuksella voidaan tähdätä yrittäjyysmotivaation lisääntymiseen, antaa mahdollisuuksia itsetutkisteluun ja yrittäjyyden kuvan tarkentamiseen.

\section{Myös konkreettiseen}

maalle siirtymiseen tähtäävää yrittäjyyskoulutusta tulisi kehittää ja tarjota. Tämänkaltaisen koulutuksen sisällössä tulisi yhdistää yrityksen perustamisneuvonta, maalle muuton tukeminen ja sopeutumisvalmennus. Edellä mainittujen osa-alueiden integrointiin tulisi kiinnittää erityistä huomiota, sillä maaseudulle siirtyminen on raportin mukaan vaativuudessaan rinnastettavissa yrittäjäksi ryhtymisen prosessiin.

\section{Yleistä yrittäjyysneuvon-} taa voitaisiin koordinoida nykyistä paremmin. Elintarviketieto Oy kysyi tutkimuksessa haastatelluilta heidän mahdollisuuksiaan ja halukkuuttaan saada yrittäjyysneuvontaa. Aihepiiriä ei raportissa käsitelty 
laajemmin, mutta todettakoon, että kohderyhmällä oli kohtuullisen hyvin tiedossaan alan runsas tarjonta. Lisätietoa haastateltavat halusivat kuitenkin saada siitä, mitkä tahot mitäkin neuvontaa antavat.

\section{Raportti tarjoaa monia} näkökulmia jatkotutkimukselle. Arvokasta lisätietoa voitaisiin saada case-tutkimuksista, joilla seurataan maalle muutta- jien päätöksentekoprosessia, sopeutumista ja toimeentulomahdollisuuksien löytymistä.

\section{Maaseudun ja kaupunkien} välinen vuorovaikutus avaa monia uusia tutkimusteemoja: työmarkkinoiden kytkennät, pendelöinti, paikallisen omatoimisuuden vahvistuminen, kulttuurivuorovaikutus ja osaamiskeskustoiminta. Mielenkiintoisia kysymyksiä herättä- vät maaseudulla jo pidempään toimineet yritykset ja yrittäjien tapauskertomukset. Kansantalouden näkökulmasta kiintoisaa olisi selvittää maaseutuyritystoiminnan aluetaloudelliset vaikutukset suorite-, kerrannais- ja johdannaisvaikutusten osalta.

Eeva-Liisa Lilja 